\title{
EDUCAÇÃO PATRIMONIAL: VIVENCIANDO OS CINCO PASSOS DA PEDAGOGIA HISTÓRICO-CRÍTICA
}

\author{
PATRIMONIAL EDUCATION: EXPERIENCING TH FIVE STEPS OF THE HISTORIC-CRITICAL \\ PEDAGOGY
}

Michele Pires Carvalho*, Eduardo Augusto Moscon Oliveira**

Instituto Federal do Espírito Santo (*)

E-mail: michelepires.c@hotmail.com

Universidade Federal do Espírito Santo $\left({ }^{* *}\right)$

E-mail: eduardomoscon@hotmail.com

\begin{abstract}
Resumo
Este trabalho descreve uma sequência didática de educação patrimonial aplicada no ensino fundamental, para alunos dos 9ㅇ anos da escola Pública "Pedro Herkenhoff", localizada no município de Vila Velha, Espírito Santo, Brasil, fundamentando-se nos cinco passos da pedagogia histórico-crítica: prática social inicial, problematização, instrumentalização, catarse e prática social final, onde os alunos se apropriam criticamente do conhecimento científico. Foram realizadas como ação pedagógica: exposição oral e apresentação de slides, debates, jogos, confecção de fantoches, teatros, confecção de miniaturas de casacas, aulas de campo, relatórios, produção de vídeos e edição de jornal. A atividade permitiu uma reflexão sobre uma educação cidadã partindo das informações prévias dos alunos sobre Patrimônio e da realidade local. Possibilitou a construção de um sentimento positivo de valorização local de forma a agir de forma crítica e responsável diante do patrimônio público socialmente compartilhado.
\end{abstract}

Palavras-chave: educação patrimonial. pedagogia histórico-crítica. sequência didática. Interdisciplinaridade. educação não-formal.

\begin{abstract}
This paper aims to describe a didatic sequence to study patrimonial education in elementary school. The Teaching Sequence was developed with students of 9o s years of Public School "Pedro Herkenhoff ", located in the municipality of Vila Velha, Espírito Santo, Brasil, basing himself on the five steps of pedagogy historical-critical: early social practice, questioning, instrumentalization, catharsis and final social practice, where students critically appropriating scientific knowledge. Were performed as pedagogical action : oral presentation and slideshow, debates, games, making puppets, theaters, making miniature jackets, field classes, reports, video production and editing newspaper. The activity allows a reflection on the civic education of the students' previous starting on Heritage and the local reality information. Possible to build a positive sense of place value in order to act critically and socially responsible to the shared public assets form.
\end{abstract}

Keywords: patrimonial education. historic-critical pedagogy. didatic sequence. Interdisciplinarity. non-formal education. 


\section{INTRODUÇÃO}

A expressão Educação Patrimonial representa a difusão de práticas desenvolvidas em diferentes contextos e locais com uma nova visão do Patrimônio Cultural Brasileiro, reconhecendo sua diversidade de manifestações culturais, tangíveis (patrimônio material, como paisagens naturais, objetos, edifícios, monumentos e documentos) e intangíveis (patrimônio imaterial, relacionados aos saberes, às habilidades, às crenças, às práticas, aos modos de ser das pessoas), como instrumento de motivação para a prática da cidadania, resgate de autoestima dos grupos culturais e estabelecimento de um diálogo enriquecedor entre as gerações (HORTA et al, 1999).

A Educação Patrimonial configura-se como um trabalho educacional realizado a partir de experiências e contato com evidências e manifestações da cultura, buscando a valorização desta herança, capacitando o cidadão para melhor usufruto dos bens, proporcionando a produção de novos conhecimentos relacionados à cultura (HORTA et al, 1999). A Educação Patrimonial objetiva motivar a prática da cidadania, diante disso, foi elaborada uma sequência didática mediada pela Pedagogia Histórico-Crítica, visto que, este método de ensino favorece o diálogo entre alunos e professor, valorizando também o diálogo crítico com a cultura acumulada historicamente.

A Pedagogia Histórico-Crítica, fundamenta-se no compromisso da educação em transformar a realidade do aluno, com o objetivo de tornar a educação uma prática para formar alunos cidadãos críticos e comprometidos com uma sociedade justa e democrática (SAVIANI, 2008). O autor situa a especificidade de educação se referindo aos conhecimentos, ideias, conceitos, valores, atitudes, hábitos, símbolos sob o aspecto de elementos necessários à formação da humanidade em cada indivíduo singular, na forma de uma segunda natureza, que se produz, deliberada e intencionalmente, através de relações pedagógicas historicamente determinadas que se travam entre os homens, destacando que:

[...] o saber que diretamente interessa à educação é aquele que emerge como resultado do processo de aprendizagem, como resultado do trabalho educativo. Entretanto para chegar a esse resultado a educação tem que partir, tem que tomar como referência, como matéria prima de sua atividade, o saber objetivo produzido historicamente [...] (SAVIANI, 2008, p.7). 
A sequência didática proposta objetiva vivenciar os cinco passos da Pedagogia Histórico-Crítica de Saviani: a prática social inicial, a problematização, a instrumentalização, a catarse e a prática social final, chamando a atenção para o caráter dialético da proposta.

Gasparin propõe uma didática para a pedagogia histórico-crítica que implica trabalhar conteúdos de forma contextualizada em todas as áreas do conhecimento humano, ou seja, em várias dimensões (conceituais, científicas, históricas, econômicas, ideológicas, políticas, culturais, educacionais), que devem ser explicitadas e aprendidas no processo de ensino-aprendizagem. A leitura crítica da realidade social possibilita um novo pensar e agir pedagógicos, tornando possível um rico processo dialético (GASPARIN, 2012).

\section{PERCURSO METODOLÓGICO}

A Sequência Didática foi desenvolvida com os alunos dos $9{ }^{\circ}$ s anos C e D da Escola Municipal de Ensino Fundamental Pedro Herkenhoff, localizada no município de Vila Velha-ES, participaram das atividades todos os 40 alunos que compõe as duas turmas no turno vespertino.

A elaboração do Projeto de Trabalho Docente-Discente na Perspectiva Histórico-Crítica seguiu as orientações do livro Uma Didática para a Pedagogia Histórico-Crítica de João Luiz Gasparin, dando ênfase aos objetivos, conteúdos, procedimentos de ensino e avaliação conforme quadro abaixo, que são procedimentos para a organização e planejamento, onde o professor deve explicitar ações para que o aluno ponha em prática o conteúdo, no Quadro 1. 
Quadro 1. Projeto de Trabalho Docente-Discente na Perspectiva Histórico-Crítica (GASPARIN, 2012).

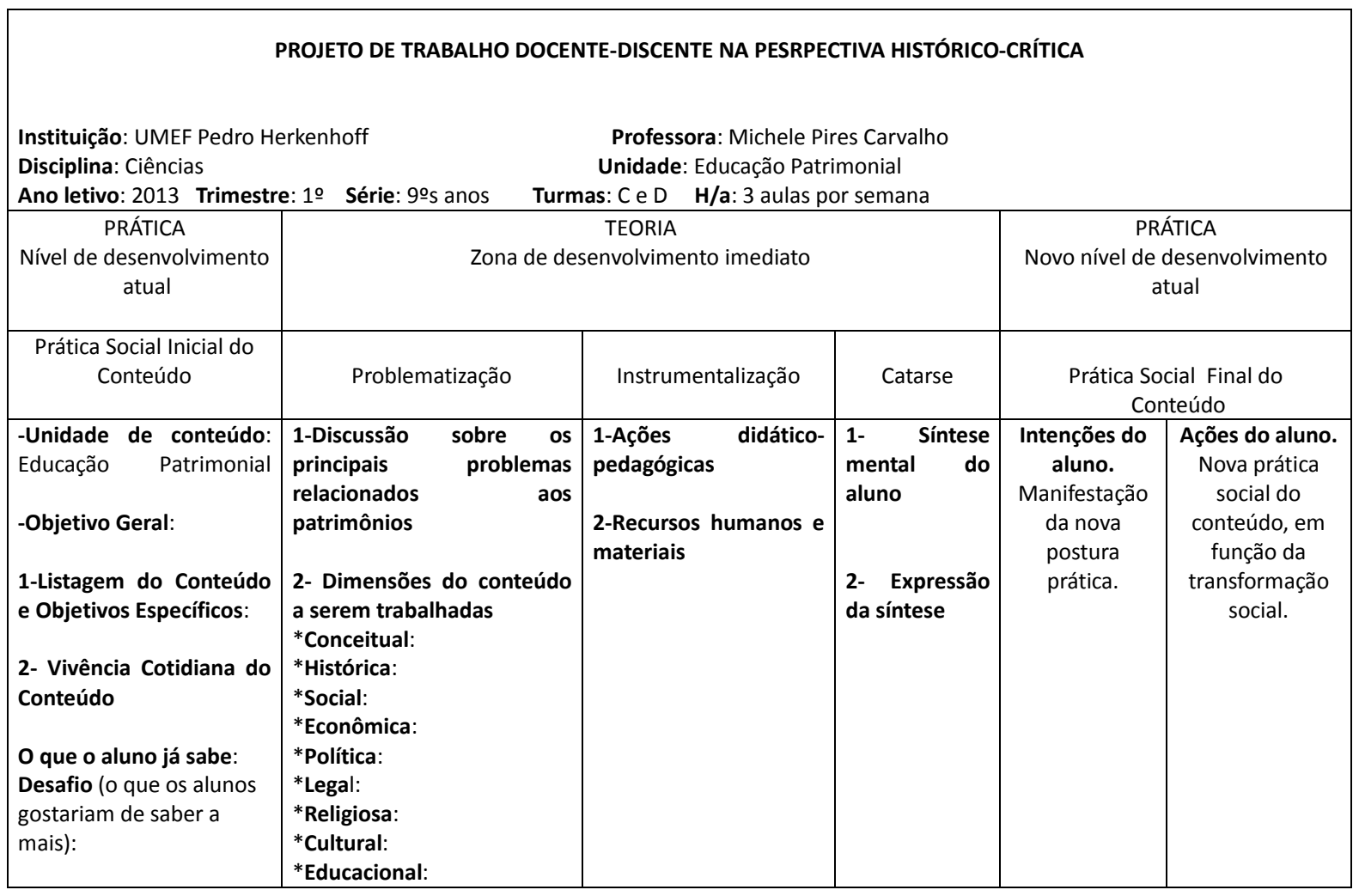

\section{RESULTADOS E DISCUSSÕES}

Fundados nos pressupostos teóricos de João Luiz Gasparin, elaboramos as seguintes atividades afim de contemplar os cinco passos da pedagogia histórico-crítica.

\subsection{Pratica Social Inicial}

O primeiro passo deste método é o contato inicial com o tema a ser estudado, sendo assim, o professor deve se apoderar dos conhecimentos prévios que os alunos detêm sobre o tema e listar os conteúdos que serão estudados. Neste momento, através do diálogo o aluno expressa suas concepções e vivências sobre o conteúdo, inicialmente a percepção do senso comum e empírica é um tanto confusa, uma visão sincrética, que não correspondem muita das vezes com o conceito científico do tema estudado. A partir daí o professor traça os principais objetivos que se pretende alcançar levando em conta duas dimensões básicas: O que aprender? Para que aprender? Esses conhecimentos devem ligar-se às necessidades dos alunos e a realidade sociocultural como um todo, contribuindo para a formação de cidadãos conscientes, críticos e participativos (GASPARIN, 2012). 
O objetivo geral foi conscientizar o educando sobre a importância da preservação dos Patrimônios, contribuindo para a construção da cidadania e valorização dos patrimônios culturais do Município e os específicos discriminados abaixo conforme relação do conteúdo trabalhado:

a) O que é Patrimônio - Conceituar o que é patrimônio, apresentando as diferenças entre o patrimônio material, imaterial e ambiental.

b) Patrimônio Material - Conhecer os patrimônios locais, buscando identificar sua importância social, cultural, econômica e histórica para o Município.

c) Patrimônio Imaterial - Conhecer as manifestações culturais ressaltando que a diversidade cultural compõe a identidade dos alunos.

d) Patrimônio Natural - conhecer as influências do comportamento das pessoas nestes ambientes, compreendendo o processo de degradação do mesmo e reconhecer o valor do Patrimônio Ambiental, promovendo a consciência de sustentabilidade.

No momento da prática social inicial a pergunta o que patrimônio foi lançada aos alunos e os mesmos responderam que se tratava de igrejas, escola, praças, monumentos, edificações, casas, ou seja, os alunos desconhecem os outros tipos de patrimônio (imaterial e ambiental), em seguida os alunos perguntam tudo o que gostariam de saber sobre o assunto (desafio), esse é o momento de contextualização do conteúdo a ser estudado, é a vivência individual e coletiva do conteúdo social que passa a ser reconstruída pelo aluno de forma sistematizada.

No momento de desafio onde os alunos expressaram os que mais gostariam de saber sobre o assunto, surgiram as seguintes questões: Por que os indivíduos historicamente situados não preservam seu patrimônio? Para que preservar os patrimônios do município? Quais são os patrimônios do município? Qual a importância desses patrimônios para o Município? Existe leis de proteção patrimonial? Essas leis são cumpridas? Por que o congo e a moqueca capixaba são considerados patrimônios e devem ser valorizados? Qual a importância dos patrimônios ambientais? O que é tombamento? Pra que serve? O congo é macumba? Folclore?

\subsection{Problematização}


O momento da Problematização representa o elemento-chave na transição entre a prática e a teoria. Na problematização, o professor elabora questões para debate, são levantadas situações problemas que estimulam o raciocínio do aluno. A problematização deve estar relacionada aos principais problemas postos pela prática social, problemas que precisam ser resolvidos não só pela escola, mas no âmbito da sociedade. Todo o conteúdo listado na prática social inicial deve ser transformado em perguntas e/ou questões problematizadoras classificando-as nas diversas dimensões, tais como: conceituais, científicas, históricas, econômicas, ideológicas, políticas, culturais, educacionais, religiosas, estéticas, filosóficas, psicológicas etc. O importante é que os alunos nesse momento se conscientizem de que problematizar significa questionar a realidade e é neste momento que se inicia a tomada de consciência crítica (GASPARIN, 2012). A problematização foi realizada conforme exposto abaixo:

Qual a importância econômica, cultural e social dos patrimônios de Vila Velha e o que eles retratam para a sociedade? Por que devemos preservar as representações culturais do município, como o carnaval de congo, as festas religiosas, a culinária e os trabalhos artesanais? Qual a importância de se preservar os rios e a mata atlântica do Município? Quais são as razões do desmatamento e da poluição dos rios? O que ameaça esses patrimônios no Município? De que forma os patrimônios envolvem a sensação de pertencimento, identidade e memória social?

Desta forma, as dimensões problematizadas na sequência didática encontram-se abaixo listadas, tendo em vista as questões que se apresentaram durante o trabalho:

a) Conceitual: O que é patrimônio?

b) Histórica: Como foram construídos esses patrimônios? Ao longo da história o homem destruiu ou modificou os patrimônios do município?

c) Social: Por que é necessário o equilíbrio do homem com os patrimônios locais? Como o homem interage com estes patrimônios?

d) Econômica: De que forma esses patrimônios contribuem com a renda da população e traz lucros para o município?

e) Política: O que a prefeitura e o estado têm feito para preservar esses patrimônios?

f) Legal: Quais são as leis de proteção patrimonial?

g) Religiosa: De que forma a igreja tem influência sobre estes patrimônios? 
h) Cultural: Quais as manifestações culturais do município e qual sua importância na construção da identidade dos moradores da região?

i) Educacional: Qual o papel da escola na preservação dos patrimônios?

Apesar da lista de dimensões estabelecidas acima, algumas das problematizações sofreram modificações e foram adaptadas a realidade do aluno no decorrer da aplicação da sequência didática.

\subsection{Instrumentalização}

Nessa fase as perguntas da problematização são respondidas. De acordo com Saviani (1999) consiste na apreensão dos instrumentos teóricos e práticos necessários para a resolução dos problemas detectados na prática social inicial e que foram considerados fundamentais na fase da problematização.

A instrumentalização é o centro do processo pedagógico, o professor desenvolve ações didáticopedagógicas para construção do conhecimento, os alunos refazem suas concepções dos conceitos cotidianos se apropriando dos conceitos científicos e a aprendizagem se efetiva (GASPARIN, 2012). $\mathrm{Na}$ fase da instrumentalização foram realizadas como ação pedagógica: exposição oral e apresentação de slides sobre o que é Patrimônio especificando o conceito e os tipos de patrimônio material, imaterial e ambiental (figura 1), além disso, debates, jogos (figura 2), confecção de fantoches, teatros com fantoches, confecção de casacas e tambores de argila em miniaturas, aulas de campo nos patrimônios, produção de relatórios das aulas de campo e vídeos. 
Figura 1: Exposição do Conteúdo.

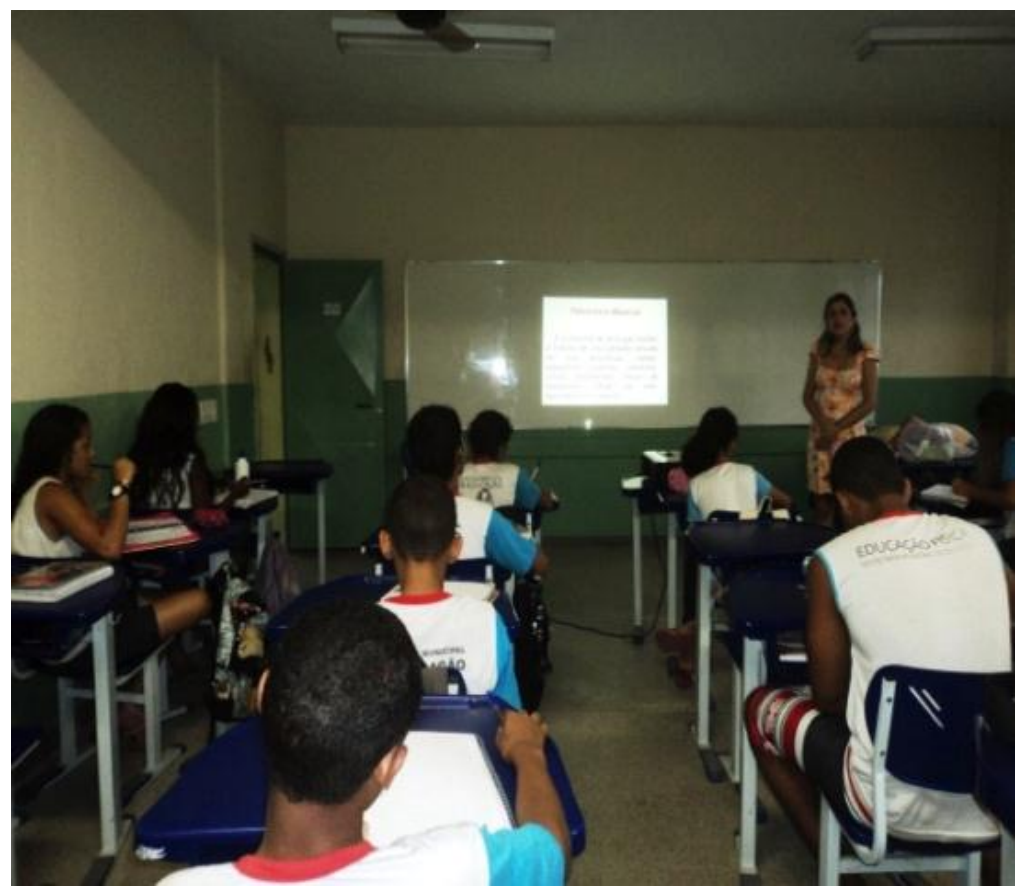

Fonte: Dados da pesquisa.

Figura 2: Jogo - Trilha dos Patrimônios de Vila Velha.

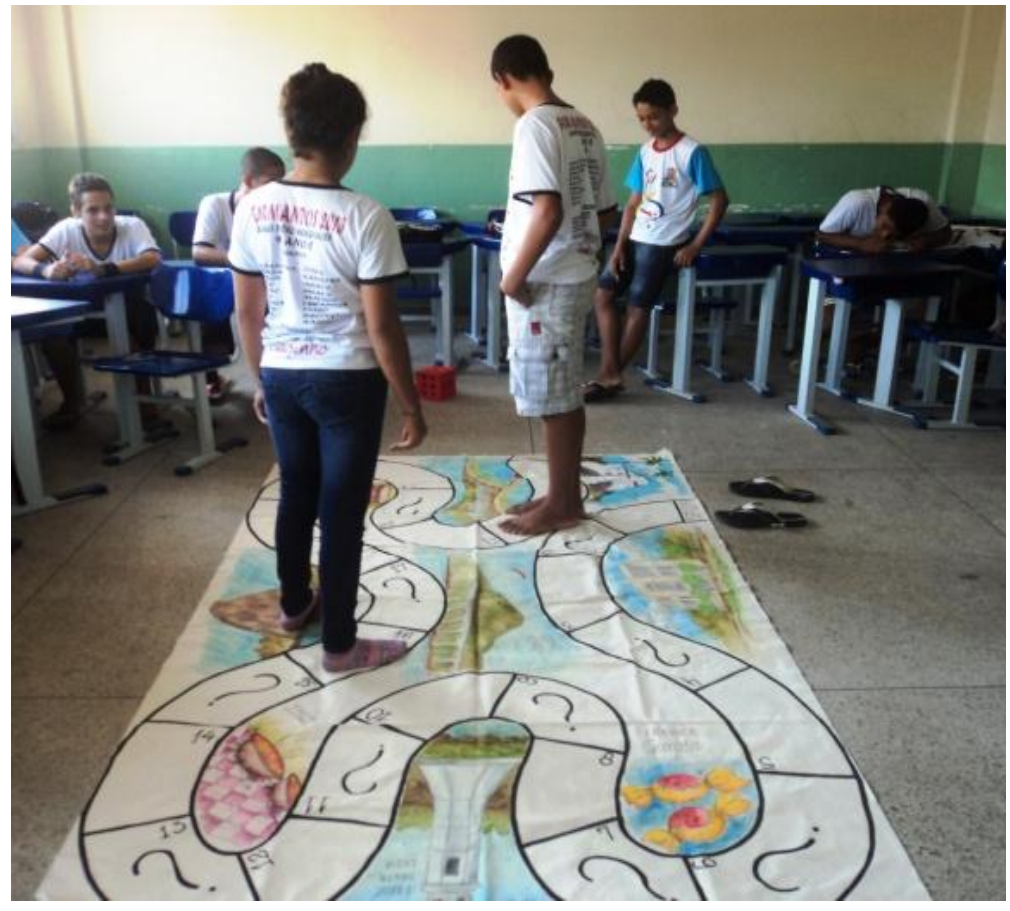

Fonte: Dados da pesquisa. 
$\mathrm{Na}$ instrumentalização foi atribuído grande valor as aulas de campo, visto que são consideradas caminhos alternativos para se construir o conhecimento. O pré-campo, o campo e o pós-campo são de suma importância para a compreensão dos alunos, uma vez que a todo o momento relaciona-se teoria e prática, pois o trabalho de campo objetiva trazer ao aluno um olhar crítico sobre a realidade e a teoria compreendendo-a dialeticamente (SILVA et al, 2010).

Os autores acima reforçam que as aulas de campo dão sentido as aulas teóricas e o aluno deixa de ser mero observador e assume o papel de investigador. Desta forma, cabe ao professor estimular a curiosidade e a criticidade dos alunos, fazendo-os enxergar as ideias, teorias e a realidade por um ângulo nunca visto anteriormente. São necessárias três etapas para se programar um trabalho de campo:

1a - Pré-campo: Etapa considerada fundamental para situar o aluno com apresentação de roteiros, objetivos da aula e finalidade daquele estudo.

2a - Campo: Não pode ser visto pelos alunos como um passeio turístico, deve ser visto como um lugar de discussão de ideias e um lugar que possibilita a compreensão da importância da prática relacionada as teorias discutidas em sala de aula. Nessa etapa o professor deve estimular a curiosidade dos alunos, para que os mesmos possam construir suas aprendizagens, instigando-os a pensar, construir e conceituar. A afetividade, o respeito de opiniões, a percepção e os debates em grupo também são trabalhados na aula de campo.

3a - Pós-Campo: Pode ser realizado de diversas maneiras desde que se faça uma leitura crítica do espaço observado, sendo assim, pode-se extrair o conhecimento dos alunos através de produção de relatórios, feiras culturais, teatros, construção de maquetes, mesas redondas ou diversas outras.

O aprendizado gerado e compartilhado na educação em espaços não formais não é espontâneo porque os processos que o produz têm intencionalidades e propostas, a mesma é voltada para a formação do ser humano como um todo, cidadão do mundo contextualizado, sendo de suma importância para a educação. O ideal é que a educação não formal seja um complemento no sentido de desenvolver os campos de aprendizagens e saberes que thes são específicos, proporcionando ao aluno, uma relação entre a teoria e a prática, atuando em conjunto com a escola (GOHN, 2010). 
As aulas de campo foram realizadas nos dias 20 e 24 de abril de 2013, com a participação dos 40 alunos, com autorização prévia da direção da escola e dos responsáveis pelos mesmos. A aula de campo teve como objetivo promover a vivência dos alunos sobre o conteúdo desenvolvido na sala de aula, reforçando a aprendizagem. Foram realizadas em dois dias, em três espaços próximos à escola e no horário de aula dos alunos. No primeiro dia os alunos puderam conhecer o Patrimônio Imaterial da região, ou seja, a manifestação cultural e a história do Congo da Barra do Jucu. No segundo dia conheceram os Patrimônios Materiais da Prainha, dentre eles a Gruta do Frei Pedro Palácio, o Museu Homero Massena, a Casa da Memória, a Igreja do Rosário, podendo também contemplar no alto do morro localizado na Prainha o Convento da Penha, objetivando resgatar a história de cada Patrimônio, se apropriando de conhecimentos sobre os mesmos e por fim o Patrimônio Ambiental situado no Parque do Morro da Manteigueira para detenção de conhecimentos sobre a fauna e flora local. As aulas de campo possibilitaram a reflexão dos alunos sobre as ameaças a estes patrimônios, promovendo a criticidade e o questionamento sobre o que podemos fazer para preservá-los. As programações das aulas de campo foram realizadas da seguinte forma:

\section{a) Patrimônio Imaterial}

08:00h - Saída da escola.

08:15h - Recepção na Barra do Jucu e encontro com o mestre de congo da banda da Barra do Jucu (Buchecha) e sua esposa.

09:00h - Ateliê Cleber Galvea (conhecer a história e as obras do artista capixaba)

10:00h - Casa de Dona Dorinha, matriarca do congo da Barra, banda tambor de Jacarenema, para conhecer os tipos de tambores, a casaca e o mastro.

10:30h - Mestre Daniel (fotos da fincada do mastro).

11:00h - Fábrica de tambor (conhecer como esses instrumentos são produzidos) e ouvir banda de congo do mestre Onório tocar.

12:00h - Fim do campo e retorno à escola

A figura 3 mostra os diferentes tipos de casacas e a figura 4 retrata a apresentação da banda de congo, com os principais instrumentos que são o tambor e a casaca. 
Figura 3: Fábrica de casaca e tambor.

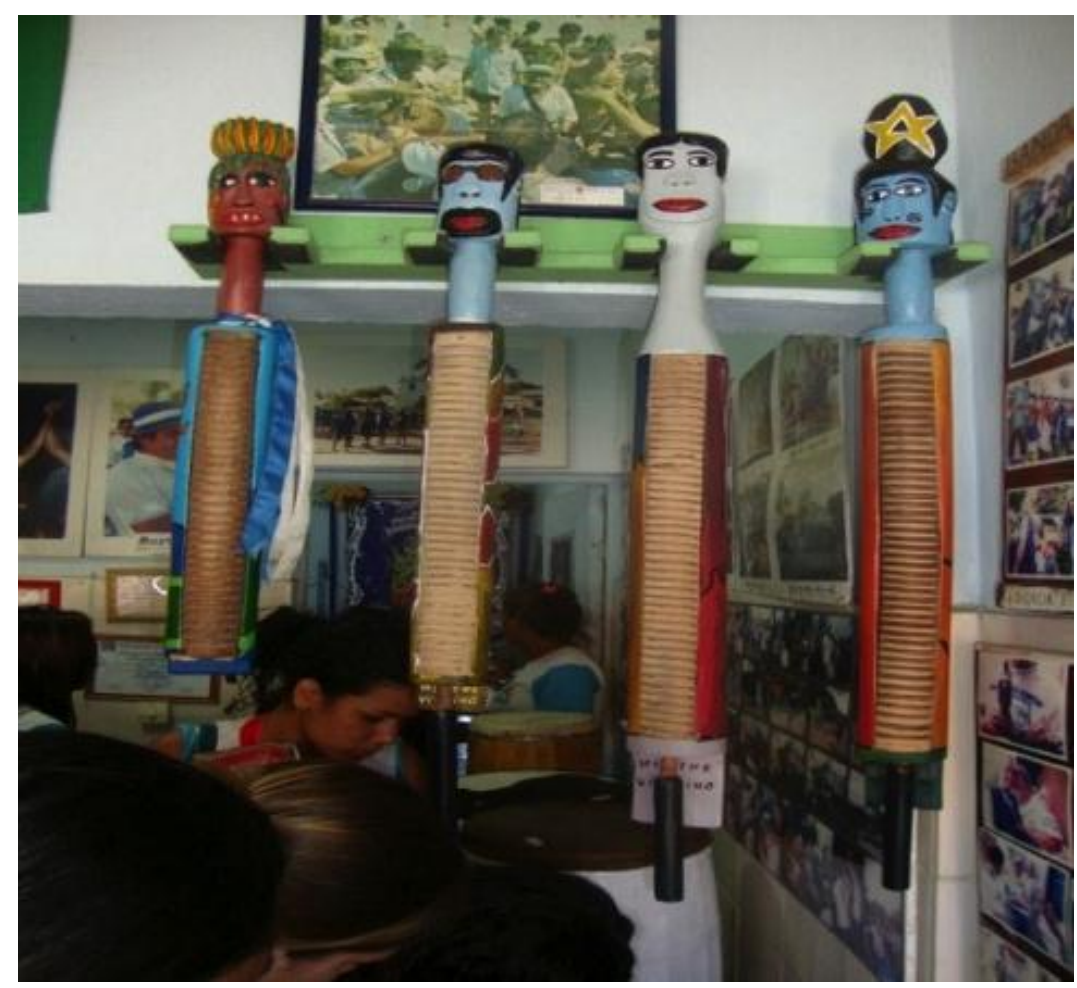

Fonte: Dados da pesquisa.

Figura 4: Roda de congo.

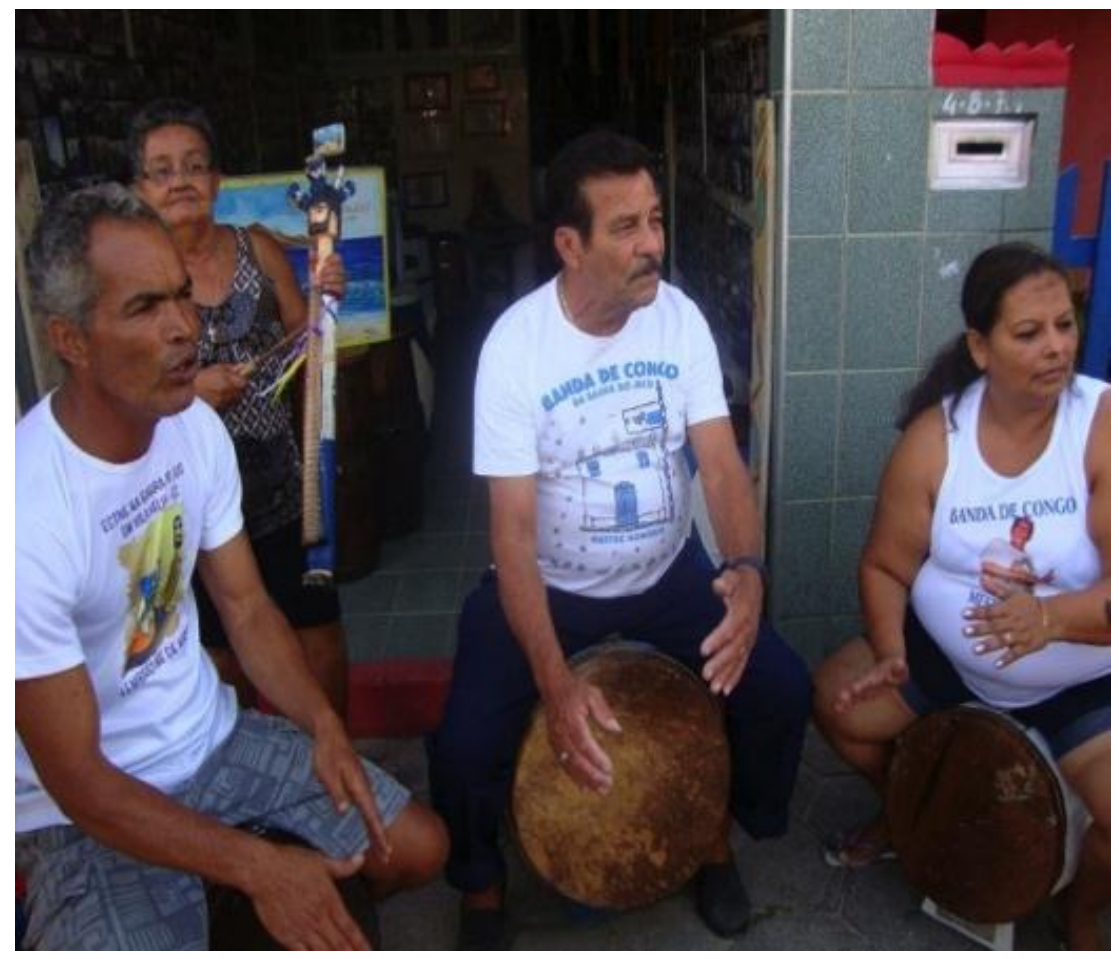

Fonte: Dados da pesquisa. 
A UNESCO (2009) define Patrimônio Imaterial como expressões de vida e tradições das comunidades e/ou grupos de indivíduos, que em todas as partes do mundo recebem de seus ancestrais e transmitem a seus descendentes. A valorização dos aspectos de um povo, como as línguas, os instrumentos de comunicação, as relações sociais, os ritos, as cerimônias, os comportamentos coletivos, os sistemas de valores e crenças devem ser vistos como referências culturais dos grupos humanos, são signos que definem as culturas e também necessitavam ser preservados (ZANIRATO, 2006). O Congo da Barra do Jucu foi um patrimônio selecionado para a sequência didática, devido às dificuldades encontradas (religiosas, econômicas) em sua manutenção e conservação.

A visita na fábrica de casacas (instrumento musical tradicional local) e tambores permitiu o conhecimento das técnicas utilizadas na confecção destes instrumentos, destacando os materiais utilizados antes e os materiais utilizados hoje, retratando a influência das novas tecnologias. Neste momento ressalta-se a importância da Educação Científica que está aliada ao movimento CTSA. Este é um movimento que surge como uma crítica às consequências da guerra e do período industrial, que trouxeram inúmeros impactos na qualidade de vida das pessoas, pois a crescente dependência tecnológica alterou as relações sociais e o ambiente (FAGUNDES, 2009).

Os estudantes devem alcançar uma certa compreensão e apreciação global da ciência e tecnologia que continuam a ser parte da cultura, o professor deve proporcionar ao aluno oportunidades para que o mesmo analise os problemas globais e considere possíveis soluções (CACHAPUZ, 2011). Em contrapartida o cidadão cientificamente alfabetizado tem a capacidade de influenciar e tomar decisões relacionadas com a ciência e a tecnologia, os iletrados no que toca a interação da ciência, tecnologia e sociedade, estão condenados a viverem isolados da cultura que os rodeia (AIKENHEAD, 2009).

Desta forma, quando relacionamos a educação patrimonial ao enfoque CTSA, o diálogo com a cultura acumulada historicamente será valorizado, o professor irá relacionar a teoria e a prática, indo além dos métodos tradicionais de ensino e por fim valorizará o contexto social do aluno e o saber produzido historicamente. 


\section{b) Patrimônio Material e Ambiental}

13:00h - Saída em frente a escola.

13:15h - Chegada na Prainha e Gruta do Frei Pedro Palácio.

13:30h - Museu Homero Massena.

14:20h - Casa da Memória e Igreja do Rosário; Divisão dos grupos para as filmagens.

15:00h - Parque do Morro da Manteigueira, Palestra (40 minutos). Trilha Ecológica - mata atlântica, fauna e flora local (vegetação arbustiva, cactos, de manguezal, mamíferos, aves, répteis, crustáceos e outros).

17:30h - Fim do campo e retorno à escola.

Durante as aulas de campo os alunos visitaram os patrimônios materiais, dentre eles os ilustrados nas figuras 5 e 7 e o patrimônio ambiental localizado no parque na Manteigueira, figura 8. Os alunos produziram vídeos e fotografias sobre os patrimônios (figura 6), responderam o questionário proposto no pré-campo e produziram relatório. A produção dos vídeos promoveu uma aprendizagem significativa, e ainda, mostrou a interpretação dos alunos diante do que presenciaram e sentiram.

Figura 5. Igreja do Rosário.

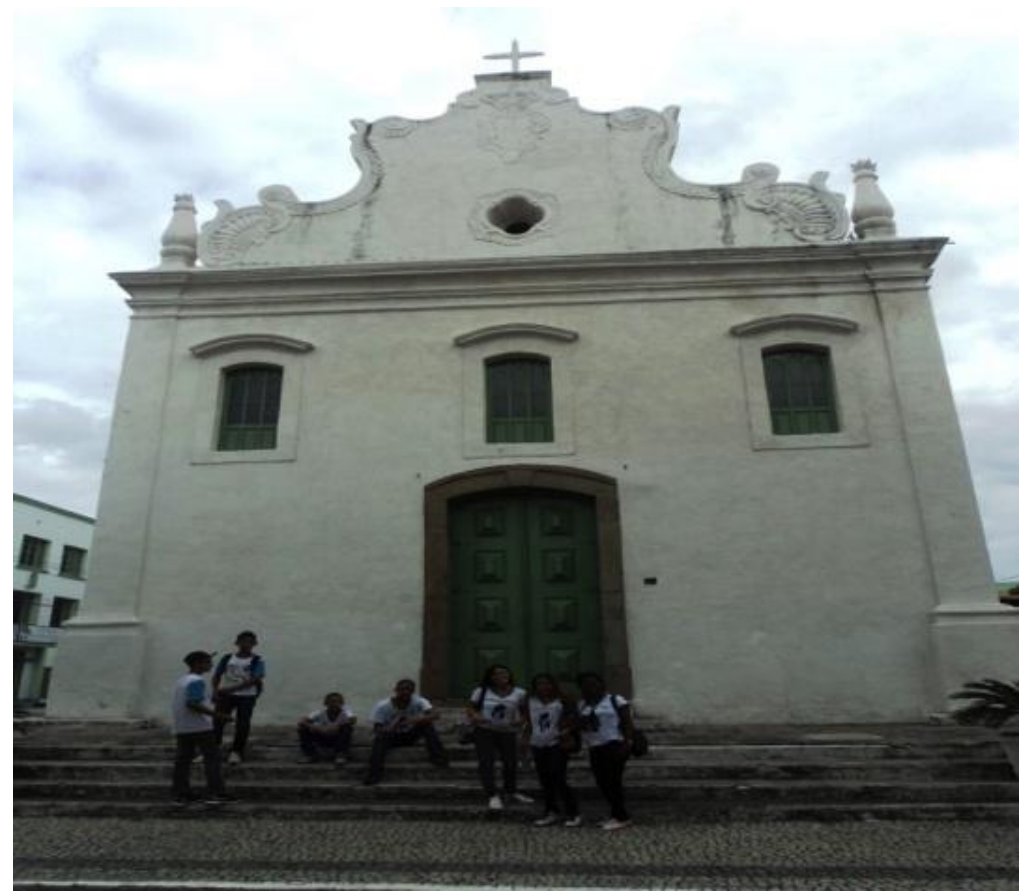

Fonte: Dados da pesquisa. 
Figura 6. Registro da gravação de vídeo sobre a importância da fauna e flora.

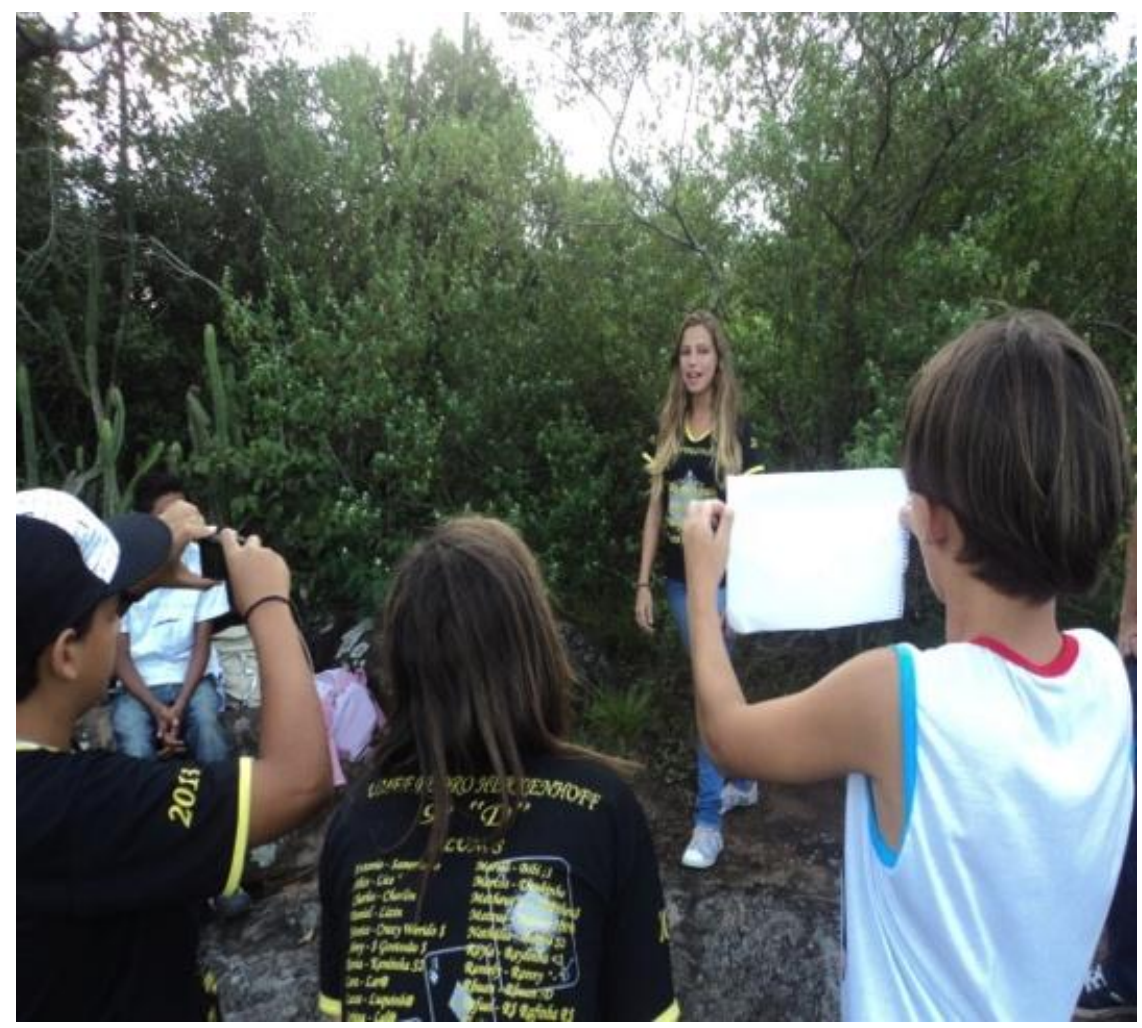

Fonte: Dados da pesquisa.

Figura 7: Museu Homero Massena.

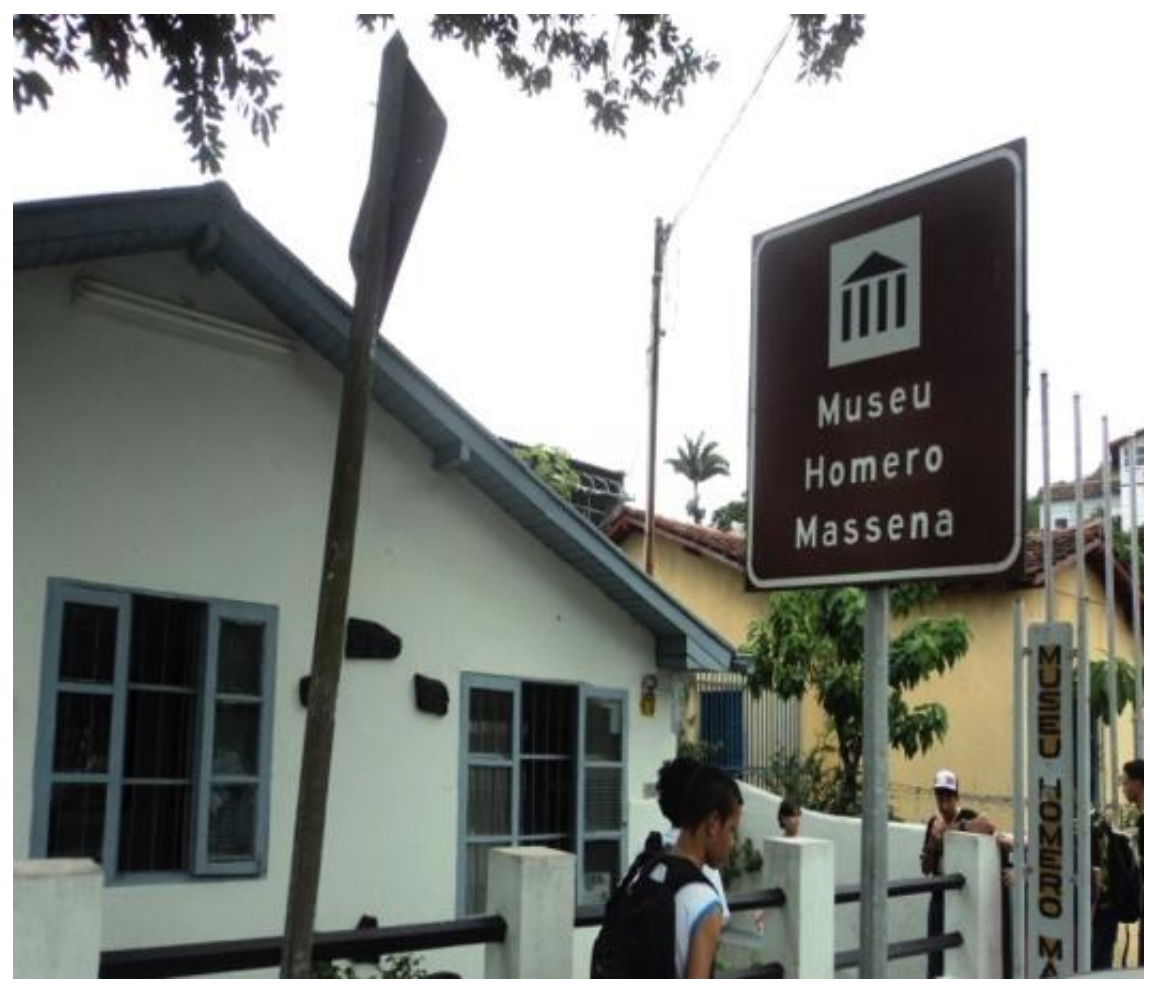

Fonte: Dados da pesquisa. 
Figura 8: Trilha do Parque do Morro da Manteigueira.

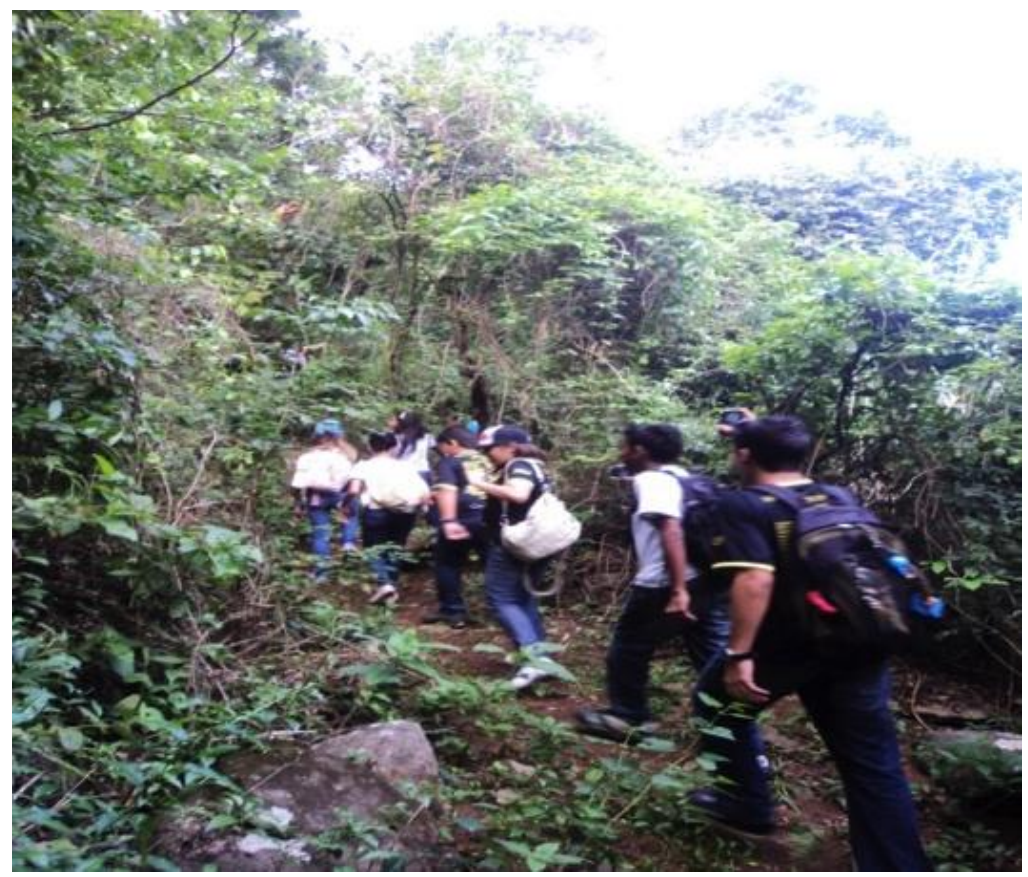

Fonte: Dados da pesquisa.

Os Patrimônios Materiais Históricos do município permitiram que os alunos pudessem realizar uma análise da situação de descaso para com o patrimônio histórico e a pouca visibilidade da tradição local, que correm o risco de perder-se pois não há envolvimento dos jovens para a cultura tradicional do município. Os monumentos, as estruturas arquitetônicas, obras de arte e outros, constituem importantes marcos na transmissão do conhecimento retratando a história local e suas contradições. São importantes na construção da identidade de uma população como forma de fortalecimento identitário. Afinal não existe identidade sem memória (FUNARI, 2001). A preocupação com o patrimônio ambiental está diretamente ligada aos recursos naturais do planeta, visto que o uso desses recursos é essencial para a garantia de uma vida digna para a população humana. Além disso, outros interesses são identificados na conservação do patrimônio natural, como por exemplo, a manutenção da biodiversidade destes locais (ZANIRATO, 2006).

\subsection{Catarse}

Na Catarse o educando sistematiza e manifesta que assimilou a si mesmo e os métodos de trabalho usados na fase anterior. Nesta fase o aluno traduz oralmente ou por escrito o compreendido em todo o processo do trabalho, é a síntese do cotidiano e do científico, do teórico 
e do prático, significa a conclusão, o resumo, ou seja, é o novo ponto teórico de chegada, a manifestação do novo conceito adquirido, neste momento ele manifesta seu novo nível de aprendizagem. Este é o ponto culminando do processo educativo onde o aluno passa da síncrese à síntese, o educando percebe que não só aprendeu o conteúdo, mas aprendeu algo que tem significado na sua vida, algo que the exige o compromisso de atuar na transformação social (GASPARIN, 2012).

O autor supra destaca ainda que para conhecer a conclusão do aluno o professor deve criar condições para que o aluno mostre o que aprendeu, deve se ressaltar que esse tipo de avaliação não ocorre somente nessa fase, mas durante todas as atividades. Essa avaliação pode ocorrer de forma informal, onde o aluno expressa de maneira espontânea o que incorporou do conteúdo, ou formal, através de questões e instrumentos propostas pelo professor. Na sequência didática desta proposta os alunos expressaram a síntese de forma informal e também formal através da confecção e realização dos jogos (figura 9 e 10), criação dos fantoches e produção do teatro (figura 11 e 12), da autoavaliação e produção de relatórios embasados nos roteiros das aulas de campo realizadas nos patrimônios da Prainha, na Barra do Jucu (congo) e no Parque da Manteigueira.

Figura 9: Confecção do jogo de memória (Patrimônio Material Imaterial e Natural).

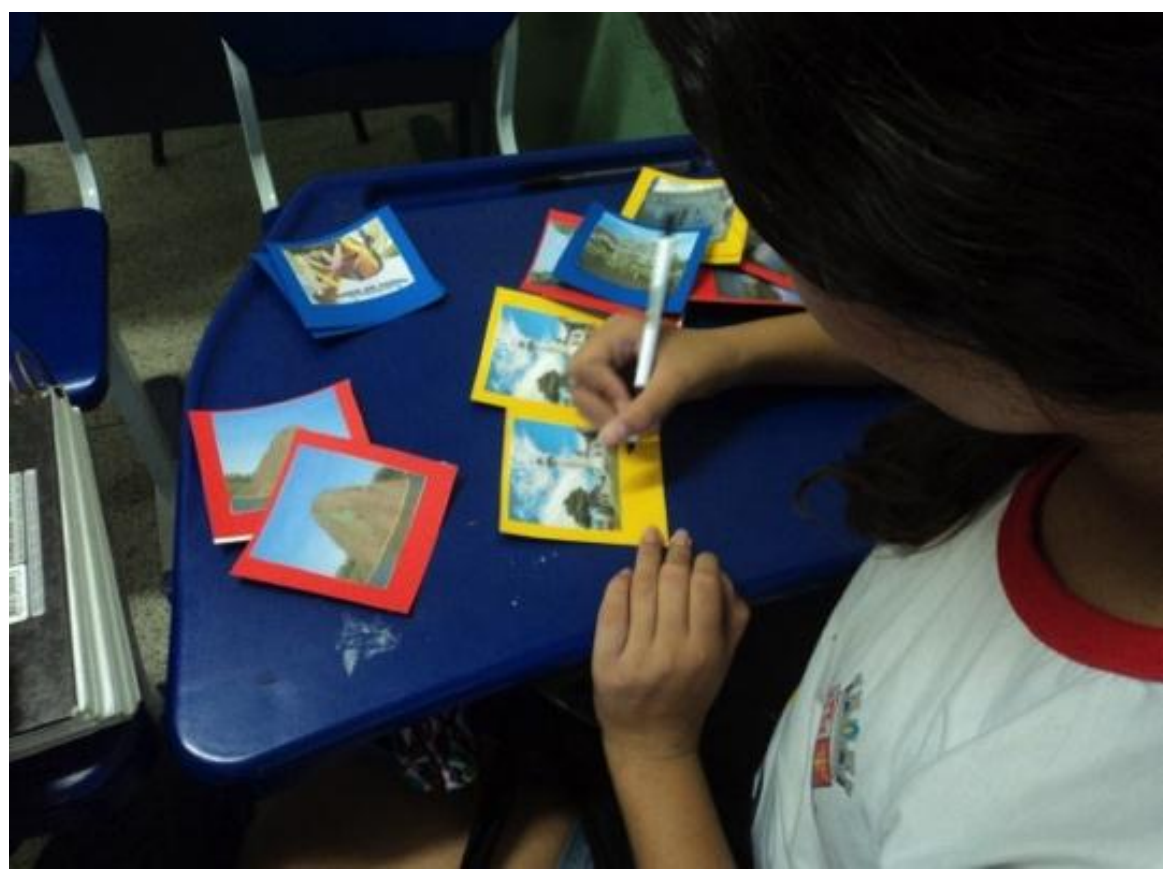

Fonte: Dados da pesquisa. 
Figura 10: Jogo de memória.

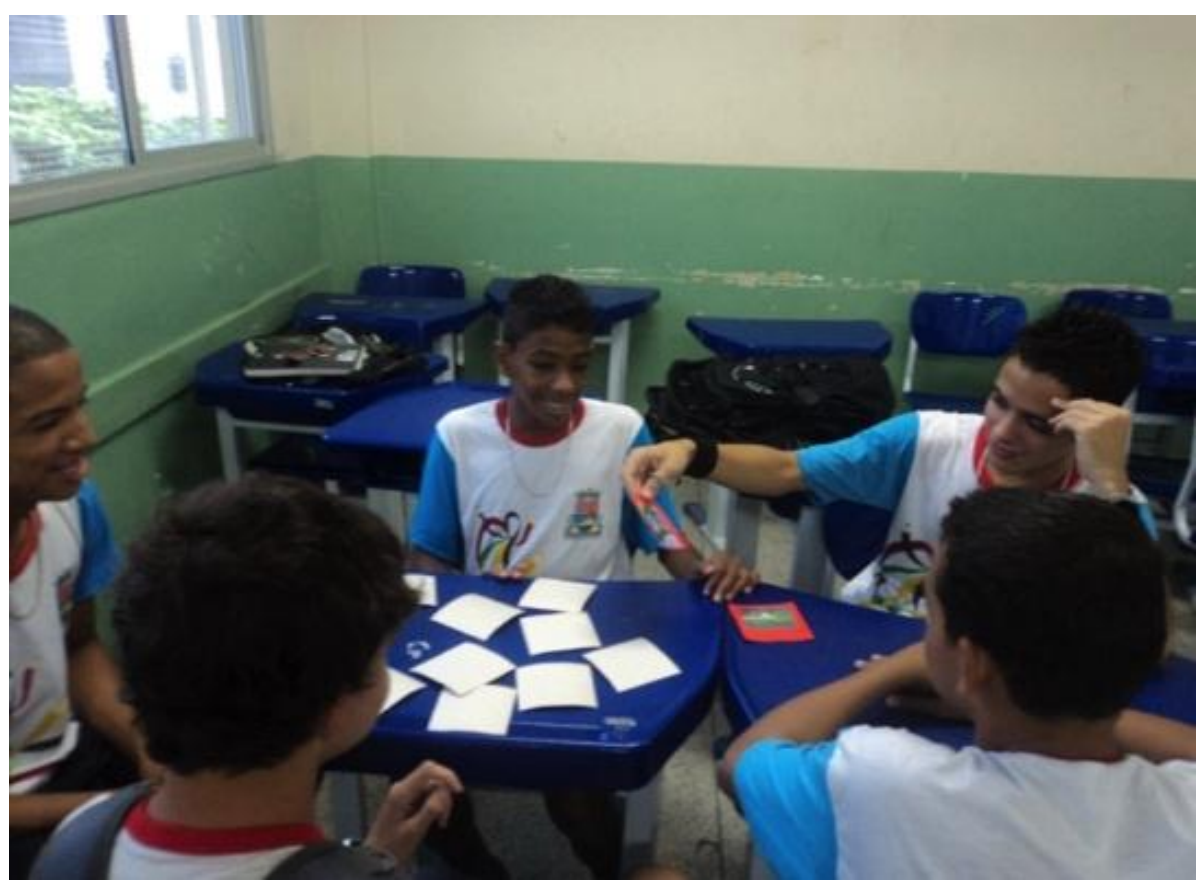

Fonte: Dados da pesquisa.

Figura 11: Confecção dos fantoches.

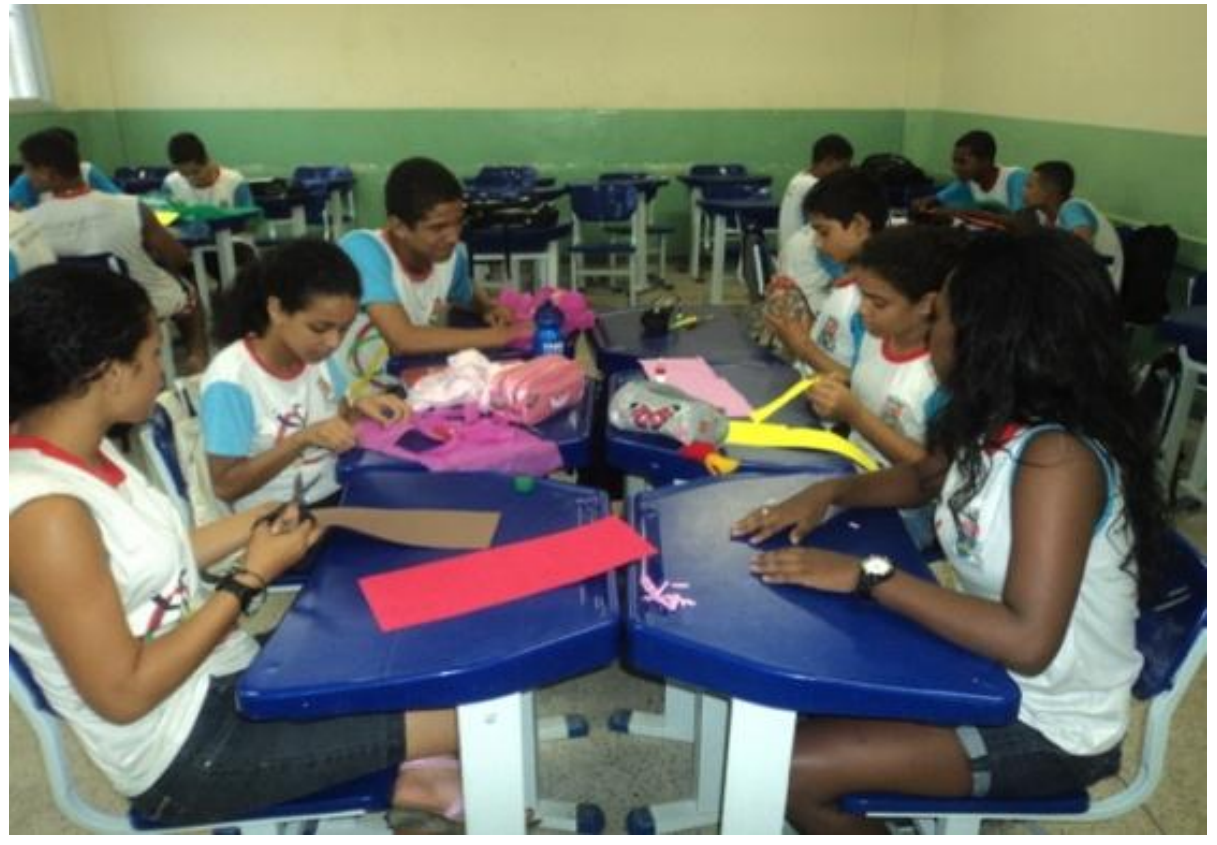

Fonte: Dados da pesquisa. 
Figura 12: Fantoches de material reciclável utilizados no teatro.

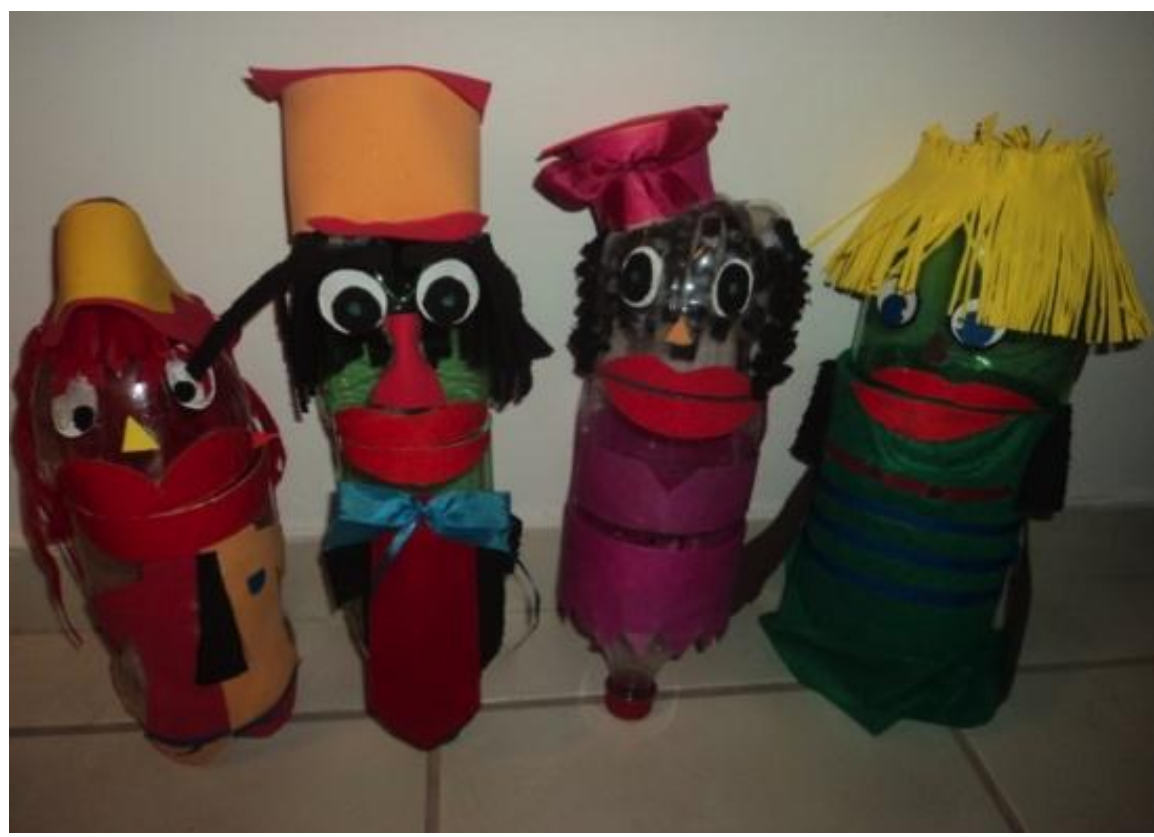

Fonte: Dados da pesquisa.

A confecção dos jogos educativos e dos fantoches despertou a essência artística dos alunos estimulando a aprendizagem, as imagens escolhidas por eles puderam expressar a compreensão dos mesmos.

Nessa etapa os alunos concluíram que Patrimônio é o termo utilizado para designar o conjunto de bens individuais ou de uma coletividade, sejam eles naturais, materiais ou imateriais (dimensão conceitual). A cidade de Vila velha - Vila do Espírito Santo, é a mais antiga do Estado do Espírito Santo, foi fundada em 23 de maio de 1535, pelo português Vasco Fernando Coutinho, a partir daí todos os patrimônios foram aos poucos sendo construídos (dimensão histórica). Muitos turistas são atraídos por estes patrimônios que se tornaram cartões postais.

O homem modificou a natureza para atender seus interesses (dimensão econômica e social). Cada grupo social possui valores diferentes e por isso possuem expressões culturais diversificadas que precisam ser resgatadas e valorizadas (dimensão cultural). Há leis de proteção destes bens (dimensão legal). Princípios religiosos também estão envolvidos nestes patrimônios, seja no carnaval de congo, na festa da penha ou com os peregrinos que visitam o convento da Penha para orações, pedidos pessoais e romarias (dimensão religiosa). Todos somos responsáveis pela preservação destes patrimônios (dimensão educacional). 
Durante as aulas de campo os alunos puderam observar que o município de Vila Velha cresce cada vez mais economicamente gerando cenários globalizados, nos quais as características locais vão perdendo espaço para os grandes empreendimentos, detectando que muitas pessoas não têm acesso à informação ao ponto de entender a importância dos patrimônios de seu município, e por isso, não comungam da necessidade de sua conservação.

\subsection{Prática Social Final}

O ponto de chegada do processo pedagógico da Pedagogia Histórico-Crítica é o retorno à prática social e nesta fase é lícito concluir que a prática social dos alunos alterou qualitativamente. $\mathrm{Na}$ Prática Social Final o aluno compreende a realidade e posiciona-se nela, manifestando sua nova postura, é o momento da ação consciente na perspectiva da transformação social, retornando a Prática Social Inicial, agora modificada pela aprendizagem (GASPARIN, 2012).

O impacto do consumismo e a globalização tem reduzido o interesse dos jovens pelos patrimônios locais, principalmente o patrimônio imaterial (o congo), devido a ligação ao mundo do consumo, com as músicas importadas. Existe uma certa rejeição à cultura do município, devido aos meios de comunicação que acabam por diminuírem as tradições coletivas locais. Segue abaixo quadro com as intenções e ações dos alunos, expressando a nova postura do aluno:

Com a finalidade de difundir o conteúdo aprendido, os alunos produziram e elaboraram um jornal para conscientizar os demais alunos da escola (Figura 13). A sequência didática pode integrar diferentes disciplinas e além disso, possibilitou uma grande socialização de conhecimentos entre escola e comunidade local. Depois de aplicada a sequência didática foi submetida à validação à posteriori por pares. A validação foi realizada com o diretor, a pedagoga, a coordenadora e com professores da escola.

De acordo com Guimarães e Giordan (2011) a validação permite uma melhor adaptação do plano de ensino, das teorias e das práticas educativas. Além de melhorar a proposta, também permite que o professor reelabore os seus saberes profissionais. Zabala (1999) reforça esse pensamento dizendo que a avaliação das sequências didáticas deve estar presente no planejamento de ensino. 
Quadro 2. Intenções e Ações dos Alunos, adaptado do Projeto de Trabalho Docente-Discente na Perspectiva Histórico-Crítica (GASPARIN, 2012).

\begin{tabular}{|c|c|}
\hline $\begin{array}{l}\text { Intenções do aluno } \\
\text { Manifestação da nova postura } \\
\text { prática. }\end{array}$ & $\begin{array}{l}\text { Ações do aluno } \\
\text { Nova prática social do conteúdo, } \\
\text { em função da transformação social. }\end{array}$ \\
\hline 1- Preservar os patrimônios locais. & $\begin{array}{l}\text { 1-Não depredar os patrimônios, inclusive o } \\
\text { patrimônio escolar, não jogar lixo nos rios e em } \\
\text { terrenos baldios }\end{array}$ \\
\hline $\begin{array}{l}\text { 2- Conhecer mais sobre a região } \\
\text { onde mora. }\end{array}$ & $\begin{array}{l}\text { 2- Entrevista com os mestres de congo e } \\
\text { compreender o início dessa manifestação cultural. } \\
\text { - Aplicação de questionário na casa da memória e } \\
\text { museu Homero Massena sobre a história e } \\
\text { importância destes patrimônios. }\end{array}$ \\
\hline 3- Aprofundar conhecimentos. & 3- Ler sobre os patrimônios da região. \\
\hline $\begin{array}{l}\text { 4- Difundir o conteúdo, valorizando } \\
\text { a identidade local. }\end{array}$ & $\begin{array}{l}\text { 4- Produzir vídeos sobre os patrimônios e } \\
\text { apresentar para as outras turmas }\end{array}$ \\
\hline $\begin{array}{l}\text { 5- Conscientizar os outros alunos da } \\
\text { escola sobre a preservação dos } \\
\text { patrimônios. }\end{array}$ & $\begin{array}{l}\text { 5- Escrever e divulgar o jornal da Educação } \\
\text { Patrimonial } \\
\text { - Expor fotos, vídeos e relatar as experiências } \\
\text { vivenciadas durante o projeto. }\end{array}$ \\
\hline
\end{tabular}

Fonte: Dados da pesquisa. 
Figura 13: Elaboração do Jornal no laboratório de Informática.

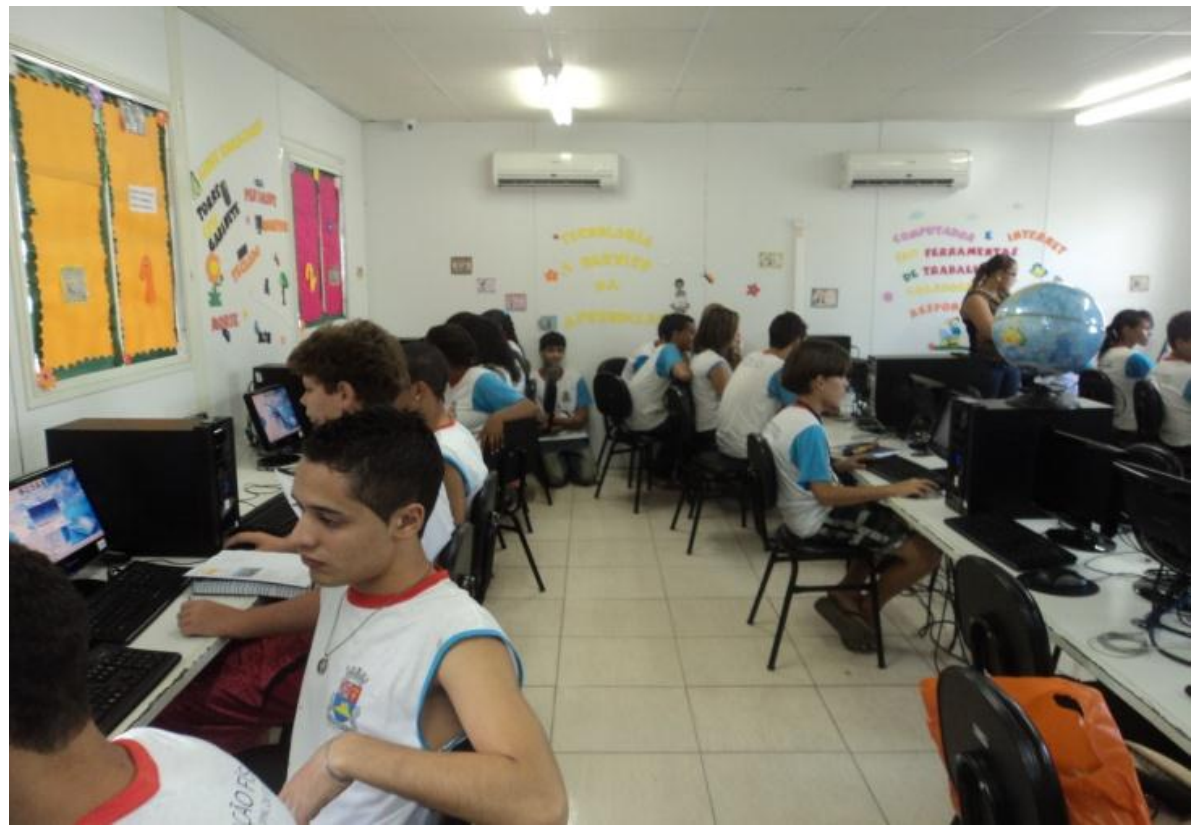

Fonte: Dados da pesquisa.

\section{CONSIDERAÇÕES FINAIS}

A Sequência Didática embasada na Pedagogia Histórico-Crítica repercutiu em uma aprendizagem satisfatória, onde os resultados mostraram motivação dos alunos com o processo de ensinoaprendizagem. Foi perceptível a participação e interação dos alunos dando as respostas nos momentos de intervenção. O bom resultado apresentado pelos alunos na Sequência Didática partiu do conhecimento prévio dos alunos até uma aprendizagem e construção de conhecimento, numa perspectiva que compreende prática-teoria-prática. É importante destacar a importância da inserção deste tema no currículo escolar de forma interdisciplinar, pois envolveu conteúdos relevantes das disciplinas de Arte, Geografia, História, Ciências, Informática e Português.

A estratégia proposta permitiu uma reflexão sobre uma educação cidadã partindo das informações prévias dos alunos sobre o estudo do Patrimônio girando em torno da realidade do aluno, levando o desenvolvimento do espírito crítico dos educandos e a construção de valores e ações que serão empregadas no seu cotidiano. A Educação Patrimonial se faz importante no que diz respeito o despertar de uma consciência crítica, possibilitando que o aluno mude suas atitudes no ambiente escolar e na comunidade, construindo um sentimento positivo de valorização de sua região, agindo 
com responsabilidade diante das questões patrimoniais, agindo de forma a garantir a sustentabilidade dos mesmos.

O objetivo principal foi conscientizar o educando sobre a importância da preservação dos Patrimônios de Vila Velha, contribuindo para a construção da cidadania e valorização dos patrimônios culturais do Município. Diante disso, os alunos detectaram a situação de descaso para com o patrimônio histórico e a pouca visibilidade da tradição local, que correm o risco de perderse pois não há envolvimento dos jovens com a cultura do município. Os jovens hoje são influenciados pelo capitalismo e vivem num mundo individualista em meio as tecnologias. Pode-se perceber que só haverá envolvimento e comprometimento com o patrimônio quando os alunos passarem a se identificar com ele, portanto, a Educação Patrimonial que propomos, diferente da tradicional, não visa ocorrer de forma forçada e incorporar, por meios impositivos, o patrimônio na identidade local. Para que se alcance uma educação progressista, todos os envolvidos devem ser entendidos como sujeitos históricos, deixando de lado o papel de expectador.

Ficou claro que no Município de Vila Velha existe certa dificuldade em incorporar uma consciência que permita valorizar os patrimônios que retratam a memória da região, pois, o foco se dá nas edificações e manifestações de caráter público, vinculado ao Estado e aos grupos dominantes, rejeitando outras tradições ou valores. Esse fato reafirma a necessidade de políticas públicas que visem reverter esse quadro através da Educação Patrimonial crítica, que supera aquilo que tradicionalmente se convencionou a denominar de patrimônio, valorizando também o espaço do indivíduo, favorecendo a diversidade de possibilidade de entendimento acerca do patrimônio. Para isso, é preciso "desprivatizar" o patrimônio e a cultura local, adequando perspectivas e vislumbrando possibilidades de participação de todos.

\section{REFERÊNCIAS}

AIKENHEAD, Glen. Educação Científica para Todos. Portugal: Edições Pedago, Lda, 2009. Tradução de Maria Teresa Oliveira.

BRASIL, Secretaria de Educação Fundamental. Parâmetros Curriculares Nacionais: pluralidade cultural, Orientação sexual. Secretaria de Educação Fundamental- Brasília: MEC/SEF, 1997.

BRASIL, Secretaria de Educação Fundamental. Parâmetros Curriculares Nacionais: meio ambiente e saúde. Secretaria de Educação Fundamental- Brasília: MEC/SEF, 1997. 
CACHAPUZ, Antônio... [et al.], (organizadores). Necessária renovação do ensino de ciências. 3.ed. - São Paulo: Cortez, 2011.

FAGUNDES, Suzana Margarete Kurzmann et. al. Produções em educação em ciências sob a perspectiva CTS/CTSA. In: ENCONTRO NACIONAL DE PESQUISA EM EDUCAÇÃO EM CIÊNCIAS, 7, Atas. Florianópolis. Atas. 2009.

FUNARI, Pedro Paulo. Os desafios da destruição e conservação do Patrimônio Cultural no Brasil. Trabalhos de Antropologia e Etnologia, Porto, 41, 1/2, 2001, 23-32.

GUIMARÃES, Y. A. F. GIORDAN, M. Instrumento para a construção e validação de sequências didáticas em um curso a distância de formação continuada de professores. VIII ENPEC, 2011. Disponível em: <http://www.nutes.ufrj.br/abrapec/resumos/R0875-2.pdf> acesso em: 01 jul, 2013.

HORTA, Maria de Lourdes P.; GRUNBERG, Evelina; MONTEIRO, Adriane Queiroz. Guia Básico de Educação Patrimonial, Brasília: IPHAN, Museu Imperial,1999.

IPHAN - Instituto do Patrimônio Histórico e Artístico Nacional. Disponível em <http:// www.iphan.gov.br>. Acesso em maio. 2012.

GASPARIN, João Luiz. Uma didática para a pedagogia histórico-crítica. 5.ed. ver., 2. Reimpr. Campinas, SP: Autores Associados, 2012. - (Coleção educação contemporânea).

GOHN, Maria da Glória. Educação não formal e o educador social: atuação no desenvolvimento de projetos sociais. São Paulo: Cortez, 2010. - (Coleção questões da nossa época, v.1).

SAVIANI, Demerval; Escola e democracia: teorias da educação, curvatura da vara, onze teses sobre a educação política/Demerval Saviani - 41. Ed. Revista - Campinas, SP: Autores Associados, 2009. (coleção Polêmica do nosso tempo, 5).

SAVIANI, Demerval; Pedagogia histórico-crítica: primeiras aproximações/Demerval Saviani - 10. Ed. rev. - Campinas, SP: Autores Associados, 2008. - (Coleção educação contemporânea).

SILVA, J. S. R; SILVA, M. B; VAREJÃO, J. L. Os (des)caminhos da educação: a importância do trabalho de campo na geografia. Vértices, Campos dos Goytacazes/RJ, v. 12, n.3, p.187-197, set/dez 2010.

UNESCO (Organização das Nações Unidas para a Educação, a Ciência e a Cultura). (UNESCO, 2009). Disponível em: <http://unesdoc.unesco.org/images/0013/001333/133369por.pdf>. Acesso em 22 set. 2012.

UNESCO (Organização das Nações Unidas para a Educação, a Ciência e a Cultura). Disponível em: <http://www.unesco.org/new/pt/brasilia/culture/world-heritage/intangible-heritage/> Acesso em 01 jun. 2013.

ZABALA, A. A prática educativa, como ensinar. Editora Artmed, 1998.

ZANIRATO. Silvia Helena. RIBEIRO. Wagner Costa. Patrimônio Cultural: A percepção da natureza como um bem não renovável. Scielo. São Paulo, Jan 2006. Disponível em <http:// www.scielo.br/scielo.php?pid=S0102-01882006000100012\&script=sci arttext $>$. Acesso em 26 nov. 2012. 